Łukasz Pigoński (Łódź)

\title{
Berichus and the Evidence for Aspar's Political Power and Aims in the Last Years OF THEODOSIUS II'S REIGN
}

\section{$\mathrm{T}$} he objective of this article is to explore the evidence for the political position of Aspar in the last years of the reign of Theodosius II. There is almost no information concerning the general's activity in the sources; only one situation mentioned by Priscus provides some evidence, albeit indirect. The event in question is the diplomatic scandal concerning a certain Berichus, a Hunnic nobleman and diplomat, who fell into disagreement with the envoy Maximinus over the latter's alleged statements concerning Aspar's incompetence and lack of influence at the court. The situation is certainly unclear and calls for further analysis.

It is important to note that scholars are not in agreement when it comes to the evaluation of Aspar's political power and goals in the last years of the reign of Theodosius II. Most researchers concentrate on the political struggle that emerged immediately after the emperor's death and involved Aspar, Theodosius's sister Pulcheria, as well as the eunuch Chrysaphius - Theodosius's all-powerful advisor. It used to be assumed routinely in the literature that Aspar retained his political power despite his military defeats at the hands of the Huns, and used it to secure the throne for his close subordinate, Marcian ${ }^{1}$.

This viewpoint was independently challenged by Ronald Bleeker and Kenneth Holum, both of whom claimed that Aspar's influence diminished severely in those years, so that he was only able to regain it through his alliance with Pulcheria ${ }^{2}$. This

\footnotetext{
${ }^{1}$ The accounts vary between those that underscore Aspar's power and influence as Kaisermacher - G. Vernadsky, Flavius Ardabur Aspar, SF 6, 1941, p. 53; A.H.M. Jones, The Later Roman Empire 284-602. A Social, Economic and Administrative Survey, Oxford 1964, p. 218; B. BACHrach, A History of the Alans in the West. From Their First Appearance in the Sources of Classical Antiquity through the Early Middle Ages, Minneapolis 1973, p. 44; A. Demandt, Geschichte der Spätantike, ${ }^{2}$ München 2008, p. 152 [= AGBHB], and those that put more emphasis on Pulcheria's role - J.B. BuRY, History of the Later Roman Empire from the Death of Theodosius I to the Death of Justinian, AD 395 to AD 565, London 1923, p. 235-236; E. STEIN, Histoire du Bas-Empire, Paris 1959, p. 311.

${ }^{2}$ R.A. BleEker, Aspar and Attila: The Role of Flavius Ardaburius Aspar in the Hun Wars of the 440s, AWo 3, 1980, p. 23-29; K.G. Holum, Theodosian Empresses. Women and Imperial Dominion in Late
} 
theory was criticized by Richard Burgess, who considers it much more likely that Pulcheria was a mere pawn in Aspar's hands, and that the commander was one of the most important people at the court ${ }^{3}$. Other scholars opt for a more balanced approach, recognizing both Aspar and Pulcheria as powerful political figures, who created a political alliance with the Isaurian general Flavius Zeno ${ }^{4}$.

There are multiple questions that remain unanswered. What was the situation on the Byzantine political scene in the last three years of Theodosius's reign, and how did the war of 447 affect it? Did Aspar ally himself with Flavius Zeno, and if so, why did the two potential rivals decide to work together? Did Aspar oppose Chrysaphius all along, or did he do so only when he saw the opportunity to secure the throne for his protégé? Only a handful of voices in the literature have attempted to deal with the problem of Aspar's actual aims. Gerhard Wirth acknowledges Aspar as one of the most powerful people at the court, considering him a proponent of pro-Hunnic policy; interestingly enough, the scholar bases his argument on Berichus's claims ${ }^{5}$. Contrary to that, Leighton Scott considers it unlikely that Aspar supported the Huns ${ }^{6}$; however, he considers the whole scandal concerning Maximinus and Berichus an expression of the former's anti-barbarian prejudice ${ }^{7}$.

Antiquity, Berkeley-London 1981, p. 206-209. Even though Holum's work seems to have much greater prominence in the scholarly literature, Bleeker's interpretation is markedly more detailed, especially considering the topic of this article; therefore, it deserves more attention. Based on the vague description by Theophanes (Theophanis Chronographia, AM 5942, rec. C. DE Boor, Lipsiae 1883-1885 [cetera: Theophanes]), Bleeker assumes that both Aspar and Areobindus held the titles of magistri militum in praesentis; however, they would have been demoted due to their unsuccessful attempts at stopping the Huns in the 440s (R.A. BleEker, Aspar..., p. 25-26). The scholar presents the events in the context of the political struggle between different ethnic groups in the army, claiming that the failure of Germanic commanders allowed the Romans and the Isaurians to gain the upper hand for a short period of time, until Aspar recovered his position with Pulcheria's help (R.A. BleEker, Aspar..., p. 27-28). This is very unlikely, however (see note 19), as it does not take into consideration some of the relevant events, such as the conflict between the Isaurian Flavius Zeno and Chrysaphius. Nonetheless, it should be noted that this is not the only interpretation that follows such train of thought. Earlier, E.A. Thомpson (The Isaurians under Theodosius II, Her 48, 1946, p. 29-30) pointed out that Aspar had a powerful political contender in Flavius Zeno, hinting at the Alan commander's losing some of his influence due to Zeno's rise to power. However, when analysing the relevant power structure, the researcher calls Zeno's lack of initiative to face Aspar "a mystery", offering no explanation.

${ }^{3}$ R.W. Burgess, The Accession of Marcian in the Light of Chalcedonian Apologetic and Monophysite Polemic, BZ 86/87, 1994, p. 27-68.

${ }^{4}$ C. Zuckermann, L'Empire d'Orient et les Huns. Notes sur Priscus, TM 12, 1994, p. 176; The Ecclesiastical History of Evagrius Scholasticus, ed. et. trans. M. Wнгтвy, Liverpool 2000 [= TTH, 33], p. 60, an. 12; A.D. LeE, Theodosius and His Generals, [in:] Theodosius II. Rethinking the Roman Empire in Late Antiquity, ed. C. KelLy, Cambridge-New York 2013 [= CCS], p. 95-96. The researcher also claims that following Aspar's defeats in 447, the general could have lost his command over the imperial armies, while Zeno's forces in the East remained unscathed; this would have rendered him the most powerful general at the time. Cf. C. Zuckermann, L'Empire..., p. 172.

${ }^{5}$ G. Wirth, Attila. Das Hunnenreich und Europa, Stuttgart 1999, p. 87-88.

${ }^{6}$ L. ScotT, Aspar and the Burden of Barbarian Heritage, ByzS 3, 1976, p. 63.

${ }^{7}$ Ibidem, p. 59. 
Roger Blockley provides a different explanation, claiming that Berichus may have simply been concerned with the influence of his Gothic compatriots in the Empire. Nevertheless, he considers Aspar to be an opponent of Theodosius II's Hunnic policy and even attributes his falling out of favour to those disagreements ${ }^{9}$.

Thus, in what follows, we shall analyse all of the available information in detail. Regrettably, not much is known about Berichus himself. According to Priscus, he was one of Attila's logades (Gr. $\lambda o \gamma a ́ \delta \varepsilon \varsigma$ ). Some scholars have attributed this term found in Priscus's account to a certain political rank within the Hunnic society ${ }^{10}$. However, it is more likely that the term simply meant 'distinguished', and, as explained by Otto Maenchen-Helfen, it did not entail any specific function ${ }^{11}$.

Nevertheless, in the case of Berichus, we have some additional information about his political position within the Hunnic society. Priscus claims that he was well-born; thus, he was likely descended from an established aristocratic line, which would have certainly helped his political standing. Additionally, he was a landowner - as related by Priscus, he ruled numerous villages in Scythia. Furthermore, he probably commanded military contingents from said settlements and was responsible for taxation in them, which would point to his having a considerable political status due to wealth, prestige, as well as military and administrative functions.

We also know that he took part in the banquet organized by Attila and sat in front of the Roman ambassador at the table. Considering that, he must have been a significant figure, yet not one of Attila's closest men, as Priscus states, that the embassy was purposefully sat at the king's left-hand side, which was to indicate its lesser status ${ }^{12}$. It follows that Berichus's place at the table was not particularly prestigious. However, we do not know whether that was due to his

${ }^{8}$ R.C. Blockley, East Roman Foreign Policy. Formation and Conduct from Diocletian to Anastasius, Leeds 1992, p. 66. A similar explanation was offered by L. Tyszkiewicz (Hunowie w Europie. Ich wpływ na Cesarstwo Wschodnie i Zachodnie oraz na ludy barbarzyńskie, Wrocław 2004 [= AUW, 2695], p. 135), with the difference that Berichus's anger would have been caused by personal grudge rather than political concern.

${ }^{9}$ R.C. BLOCKLEY, East..., p. 67.

${ }^{10}$ According to some scholars, they were responsible for collecting taxes and leading the tribal contingents in battle. Distinct from the original aristocracy, they would have been closely connected to - or even personally picked by - the king himself. See E.A. Thompson, A History of Attila and the Huns, Oxford 1948, p. 163-166; F. Altheim, Geschichte der Hunnen, vol. IV, ${ }^{2}$ Berlin 1975, p. 281; T. Stickler, Die Hunnen, München 2007, p. 85-87; M. Rouche, Attila. La violence nomade, Paris 2009, p. 259; H.J. Kiм, The Huns, Romans and the Birth of Europe, Cambridge 2013, p. 57-58.

${ }^{11}$ O. Maenchen-Helfen (The World of Huns. Studies in Their History and Culture, ed. M. Knight, Berkeley-London 1973, p. 194-195) argues that the meaning of the word could be close to the term optimates, used by Ammianus Marcellinus in a similar context when describing the nobility of barbarian tribes.

${ }^{12}$ Priscus, Fragmenta, fr. 13, [in:] The Fragmentary Classicising Historians of the Later Roman Empire. Eunapius, Olympiodorus, Priscus and Malchus, vol. II, ed. et trans. R.C. BlOcKLEY, Liverpool 1983 (cetera: PrISCUS). 
relatively low political position, or rather due to the fact that he probably had diplomatic experience with the Romans: the latter circumstance could have been the reason for him to keep company with Maximinus and his compatriots.

This claim could be supported by the fact that Berichus was indeed sent on an envoy's duty to Constantinople, accompanying Maximinus's embassy on the way back home. We have reasons to think that the Huns, unlike the Romans ${ }^{13}$, preferred to specialize their diplomats. At least that was the case in the earlier period, when we hear of Eslas, the diplomat of king Ruga, usually carrying out diplomatic talks with Romans ${ }^{14}$. However, the preceding Hun embassy to Constantinople was conducted by Orestes and Edeco, which would indicate that Attila tended to shuffle his emissaries more, or perhaps that Berichus had fallen out of favour. Be that as it may, it is quite doubtful that he would have been chosen for an envoy without previous experience. We can assume, therefore, that he was at least moderately knowledgeable in internal Roman matters and perhaps even knew some Greek (which would have been an excellent reason for him to be seated at the envoys' table $)^{15}$.

When Berichus accompanied the Romans, everything was going as planned until the group crossed the border; Priscus even mentions that they considered the Hun to be gentle and friendly. Afterwards, however, something happened, and the Romans were quite at a loss to understand what had gone wrong. For some reason, Berichus changed his attitude towards them completely. Firstly, he took back the horse that he had given as a gift to Maximinus back in the land of the Huns by order of Attila ${ }^{16}$. Furthermore, he refused to ride together with the Romans, nor was he willing to dine with them. This awkward situation continued as the envoys travelled from Philipopolis to Adrianople, where they decided to attempt a reconciliation with the Hun. They approached him, clearly not understanding the reason for his anger and silence, claiming that they had done him no wrong; they asked him to accompany them for dinner. However, the barbarian remained unswayed. After they reached Constantinople, Priscus explains, the company hoped that Berichus would cool down his temper, and that his anger would finally wear off. That did not happen. However, at long last, he explained the reason for his change of attitude, in a furious outbreak that Priscus attributes to his savage nature. Apparently, he was angered because of Maximinus's actions back in Scythia, about which he had learned shortly before by overhearing a conversation between caravan hands accompanying the embassy. He heard that Maximinus had told Attila that the

\footnotetext{
${ }^{13}$ In the case of the Romans, it was usually the closest available military commander - B. Croke, Anatolius and Nomus: Envoys to Attila, Bsl 42, 1981, p. 165-166.

${ }^{14}$ Priscus, fr. 2.

${ }^{15}$ E.P. GlušAnin (Военная знать ранней Византии, Варнаул 1991, p. 108) actually claims that Berichus was close to Chrysaphius; unfortunately, however, he does not explain his reasoning or provide any sources supporting his assertion.

${ }^{16}$ Priscus (fr. 14) explains that Attila wanted his logades to show friendship to the Roman guests by giving them gifts.
} 
generals Areobindus and Aspar had no importance at the Constantinopolitan court and that he had undermined their achievements by calling them unreliable barbarians ${ }^{17}$.

This, however, does not explain much; rather, it leads to many further questions. Why did Berichus get so gravely insulted by Maximinus's actions? Let us recall that, ordered by Attila himself to accompany the Romans, he nevertheless rode alone, not saying a word to them during the whole way. He also saw fit to take away the gift given earlier to Maximinus - a thoroughly undiplomatic deed. Thus, it would be no understatement to refer to the incident in question as a serious diplomatic scandal. Furthermore, why did Berichus, a Hun and companion of Attila, care in the slightest for Aspar and Areobindus, two Roman generals of barbarian origin, and for their achievements being recognized? ${ }^{18}$

One of the reasons could have been that Berichus simply thought that Maximinus's statements were false. To some extent, this may have been the case: while the political position of Aspar and Areobindus doubtless suffered due to their failure to defend Thrace against the Huns, it would have been quite unlikely for the generals to hold no importance at all at the court of Theodosius II, and to have no say in political matters. This applies especially to Aspar, who was connected by marriage with Plintha and Theoderic Strabo, thus enjoying the support of the Gothic foederati who inhabited Thrace ${ }^{19}$. The several thousand barbarian warriors

${ }^{17}$ Priscus, fr. 14.

${ }^{18}$ R.C. BLOCKLEY's (East..., p. 66) argument seemingly answers this question very well; however, it builds upon the notion that barbarians of similar ethnic origins shared a common identity - a widespread assumption in older literature, especially regarding Aspar and his loyalties. His relationship with Geiseric was based on the fact that Aspar was of Alan descent (G. Vernadsky, Flavius..., p. 58-60; E. Gautier, Genséric. Roi de Carthage, Paris 1951, p. 253-254, 264; A. Bachrach, A History..., p. 45. See also K. Vössıng, Das Königreich der Vandalen. Geiserichs Herrschaft und das Imperium Romanum, Darmstadt 2014, p. 45, who supports the idea, albeit in a more balanced manner - he claims that Aspar had an advantage in coming to an agreement with the king because of his background) and the conflict with Leo I, which supposedly ran along ethnical lines in the army - between the pro-Aspar Germans and the Isaurians supporting the emperor. J.B. BuRY, History..., p. 316-318; E. Stein, Histoire..., p. 358-361; A. Demandt, Geschichte..., p. 155-156; A.D. Lee, The Eastern Empire: Theodosius to Anastasius, [in:] CAH, vol. XIV, p. 46-47. However, it has been successfully proved by B. CRoke (Dynasty and Ethnicity. Emperor Leo I and the Eclipse of Aspar, Chi 35, 2005, p. 147-203) that those assumptions were false; his argument can be extended to disprove the existence of a common barbarian identity between Roman generals of barbarian origin and the barbarian people. See also: C. Zuckermann, L’Empire..., p. 176; M. Wilczyński, Gejzeryk i “czwarta wojna punicka", Oświęcim 2016, p. 104-105. Interestingly, one of the recent articles on Aspar by M. McEvoy (Becoming Roman? The Not-So-Curious Case of Aspar and the Ardaburii, JLA 9, 2016, p. 504) - while in agreement with the aforementioned notion - claims that the general and his family constituted an exception, and they made conscious efforts to retain their non-Roman character. ${ }^{19}$ A.H.M. Jones, The Later..., p. 221; R. Blockley, East..., p. 67; A. Demandt, Geschichte..., p. 155. It is possible, however, that this alliance was only augmented by marriage later in the $460 \mathrm{~s}$, in response to Leo's support for Zeno-Tarasikodissa and the imminent political conflict. Cf. P. HeAther, Goths and Romans 332-489, Oxford 1991 [= OHM], p. 254-255. 
were certainly a factor to be reckoned with, the more so because some of them were introduced into Aspar's own personal retinue of bucellari; their loyalty to him was even proverbial ${ }^{20}$. In addition, he owned numerous estates and considerable wealth $^{21}$, as well as possibly had connections in the administration, senate, and at the court. Finally, it should be noted that he in fact managed to elevate his close subordinate Marcian - a lower-rank officer with no political capital - to the throne in 450 .

Another reason why Maximinus may have offended Berichus is that he made the opponents of the Huns look incompetent and weak. This could have been a personal matter, as Berichus had probably taken part in the fighting. In other words, we should not overlook such things as his pride, which may have been a sufficient reason for his outburst. This, however, would suggest that the Hunnic victories of 447 were not as one-sided as is generally assumed ${ }^{22}$ - for which there are also certain other indications. The only battle of 447 described by the sources is the one on the Utus river. While the final outcome was catastrophic for the Romans, who were defeated, this was due to the fact that the retinue of army leader Arnegisclus

${ }^{20}$ As illustrated by the example of Ostrys (Ioannis Malalae Chronographia, XIV, 40, rec. I. Thurn, Beriolini-Novi Eboraci 2000 [=CFHB.SBe, 35]). For a more in-depth look at Aspar's retinue, see A. Laniado, Aspar and His Phoideratoi: John Malalas on a Special Relationship, [in:] Governare e riformare l'impero al momento della sua divisione. Oriente, Occidente, Illirico, ed. U. Roberto, L. MECELLA, Rome 2016 [= ColEFR, 507], p. 325-344. E.P. GLUŠANIN (Военная..., p. 111) doubts whether Aspar had his own retinue seem unsubstantiated. See also A. URBAnIEC, Wplyw patrycjusza Aspara na cesarska elekcję Leona, USS 11, 2011, p. 185-189.

${ }^{21}$ M. McEvor, Becoming..., p. 494-495.

${ }^{22}$ J.B. Bury, History ..., p. 275; A.H.M. Jones, The Later..., p. 193; A. Demandt, Geschichte..., p. 140; H.J. KIM, The Huns..., p. 71. It is, however, more likely that the sense of dread and defencelessness detectable in the sources comes primarily from the fact that Constantinople's fortifications had been damaged in an earthquake, and had to be hastily repaired (The Chronicle of Marcellinus, a. 447, ed. et trans. B. Croke, Sydney 1995 [= BAus, 7], cetera: Marcellinus). The Huns, in fact, reached the outskirts of the capital, approaching as far as to Thermopolis (Attila usque ad Thermopolim infestus advenit - MARCELLINUS, a. 447; not Thermopylae, as is sometimes wrongly assumed. Concerning this misconception see J. Karayannopulos, Byzantinische Miszellen, [in:] Studia in honorem Veselini Beševliev, ed. V. Georgiev, Sofia 1978, p. 490; J. Prostro-Prostyński, Attila and Novae, [in:] Novae. Legionary Fortress and Late Antique Town, vol. I, A Companion to the Study of Novae, ed. T. Derda, P. DyczeK, J. Kolendo, Warsaw 2008, p. 137, an. 24.). The outcome of the ensuing peace settlements was disastrous. G. WirTh (Attila..., p. 94) provides an interesting counterpoint, considering the outcome of Attila's 447 campaign a Hunnic defeat. While there is certainly some truth to his argument concerning the long-term effects of this endeavour, the researcher goes somewhat too far in his reasoning; after all, for the Romans, the aftermath was decidedly worse. With Naissus abandoned, Serdica destroyed, and with Constantia, Ratiaria, Acadiopolis and other cities sharing a similar fate (Theophanes, AM 5942), the Roman losses cannot be overstated. The author of the Gallic Chronicle of 452 mentions seventy destroyed cities and even goes as far as to blame the West for its indifference and lack of help (Chronica Gallica a.CCCCLII, 132, [in:] Chronica Gallica, ed. T. Mommsen, Berolini 1892 [= MGH.AA]). A much more balanced overview is provided by O. MaenChen-Helfen (The World..., p. 125). 
got caught in an encirclement; when the general was struck down, the whole army scattered $^{23}$. However, Marcellinus Comes speaks of a bloody battle, which suggests high casualties on both sides. Some scholars note that the campaign of 447 was likely a costly endeavour for Attila and his army, and the Roman forces were a formidable opponent ${ }^{24}$.

The question arises whether Aspar and Areobindus's forces accompanied the army of Arnegisclus, and whether the defeat in the battle of the Utus may have been what Maximinus had in mind when talking to Attila. This is possible, but no source mentions other leaders than Arnegisclus himself ${ }^{25}$. Conceivably, the Romans planned to consolidate their units, but Arnegisclus's detachment was caught by the main Hunnic forces on the way from Marcianopolis to the rallying point with the forces from the western parts of the Balkans. Even assuming that Aspar and Areobindus's detachments were still in fighting condition after Utus (regardless if they had taken part in the battle or not), it would have been highly risky to engage the superior Hun forces ${ }^{26}$. Aspar was certainly no risk-taker, which is apparent from his campaigns against the Vandals in Africa (when he decided to stall by defending Carthage after one unlucky battle ${ }^{27}$ ) or the campaign against Dengizich (when he only engaged the enemy after gathering every available army in the $\left.\operatorname{area}^{28}\right)$. Therefore, this theory is consistent with the commander's behaviour in other similar situations, and it is likely that Aspar intended to wait for reinforcements before engaging in battle with the Huns.

\footnotetext{
${ }^{23}$ Marcellinus, a. 447; Iordanes, Romana, 331, [in:] Iordanis Romana et Getica, rec. T. Mommsen, Berolini 1882 [= MGH.AA]; Chronicon Paschale, a. 447, vol. I-II, ed. L. Dindorfius, Bonnae 1832 [= CSHB, 14-15].

${ }^{24}$ E.A. Thompson, A History ..., p. 92-93; G. Wirth, Attila..., p. 73, 94.

${ }^{25}$ The only source that names other commanders is Theophanes (AM 5942); however, his account is chronologically chaotic and he mentions the defeats in general, not the battle of the Utus specifically. Nevertheless, some scholars are of the opinion that Attila confronted the bulk of Roman forces there, including Aspar and Areobindus's detachments. See: Е.П. ГлушАнин, Военная..., p. 109; K. FeLD, Barbarische Bürger. Die Isaurier und das Römische Reich, Berlin 2005, p. 214. An interesting alternative interpretation is put forth by C. KeLLY (Neither Conquest nor Settlement: Attila's Empire and Its Impact, [in:] The Cambridge Companion to the Age of Attila, ed. M. MAAs, Cambridge 2015 [= CCAW], p. 200-201), who claims that the Roman forces were divided in order to block all approaches to Constantinople, stopping the Huns from reaching the city before the walls got rebuilt. However, the scholar assumes that the battle of the Utus took place when Attila's forces were already marching back home, which is highly dubious.

${ }^{26}$ I. BónA (Das Hunnenreich, Stuttgart 1991, p. 85) claims that the Roman army was still able to fight after Utus and it took up the responsibility of defending the capital. The scholar fails to take Zeno's troops into account, however.

${ }^{27}$ Procopius, History of the Wars, III, 3, 34-35, vol. II, Books 3-4. (Vandalic War), trans. H.B. DewING, Cambridge Massachusetts 1916 [= LCL, 81].

${ }^{28}$ Priscus, fr. 49; T.S. Burns, A History of the Ostrogoths, Bloomington 1984, p. 54. The sources mention the combined forces of Anagastes, Aspar and Ostrys, and possibly those of Basiliscus and Anthemius as well.
} 
The next battle in the campaign of 447 took place on the Chersonesus. It is only referred to at the beginning of the fragment by Priscus; its outcome is left unmentioned, however, and we never learn who led the imperial army ${ }^{29}$. The result was presumably undecided, or the Huns may have suffered a close defeat; this would explain why we hear nothing of their further attempts at attacking Constantinople, with Attila actually agreeing to a cease fire. On the other hand, Priscus claims that the Romans only acceded to the treaty because their leaders were overwhelmed by fear ${ }^{30}$. Could this mean that those leaders were Aspar and Areobindus, or is Priscus criticizing Theodosius II and Chrysaphius for making no attempts at confronting the Hunnic menace? ${ }^{31}$

Notwithstanding, we know for certain who was not afraid, and who most certainly wanted to continue the campaign and pursue the Huns: that was Flavius Zeno, who had rallied a detachment of hardy Isaurian mountaineers to defend Constantinople. We can assume that those forces were involved in the battle of Chersonesus; if we consider that the Romans could have concentrated the forces of Aspar, Areobindus, Anatolius, and Zeno, it is likely that this formidable army would have managed to hold its ground ${ }^{32}$. If the Hunnic forces were pushed back, it is no wonder that Zeno saw an opportunity to chase and destroy the enemy.

Still, all evidence suggests that the saviour of Constantinople was not allowed to pursue his ambition: the high command of the imperial forces was given to someone else. Although the sources do not state exactly who it was, we have good reasons to assume that the position was given to Anatolius. It was a common practice for the Romans to send commanding generals of nearby forces to conduct diplomatic talks with the barbarians, so that Anatolius's involvement in signing the treaty with the Huns may be a clue. The conditions of the ensuing treaty were very harsh; yet, one can understand the situation of Theodosius II and Chrysaphius, who decided that seeking an agreement would be the best course of action. After all, chasing the Hunnic army through the Balkans could have taken a lot of time ${ }^{33}$ and would have hardly prevented them from laying waste to Roman provinces

\footnotetext{
${ }^{29}$ Priscus, fr. 9, 3 - The description of the battle was presumably placed in between the second and third fragments of the Excerpta de Legationibus Gentium ad Romanos; since it did not contain information about the diplomatic exchange, it was omitted by the compiler.

${ }^{30}$ Priscus, fr. 9, 3.

${ }^{31}$ R.C. BlOckley (The Fragmentary..., p. 237) translates toủ ä

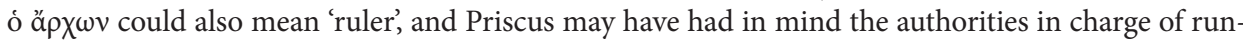
ning the empire, not military commanders. This argument could be supported by the fact that the historian is generally condescending of the regime of Theodosius and Chrysaphius. Cf. PRIscus, fr. 3 . ${ }^{32}$ In this case, we would have to assume that the battle of Chersonesus took place after the Hun forces had approached Constantinople.

${ }^{33}$ To name a parallel example, we know that dealing with Dengizich, whose army got decisively defeated in the battle of 467 (Priscus, fr. 49; T.S. BuRns, A History..., p. 54), which was certainly not the case with Attila in 447, took Romans two years till 469. Marcellinus, a. 469.
} 
until a decisive battle was fought. The outcome of the latter, considering the previous record, was by no means certain for the Romans. Realpolitik aside, this decision was highly unpopular, especially when it turned out that the Huns were by no means willing to leave the occupied $\operatorname{areas}^{34}$. Furthermore, to pay off the tribute required by the treaty, the inhabitants of the Balkans - who had just experienced Hunnic hordes ravaging their lands - had to endure new taxes levied by the central government. We hear from Priscus about the aftermath of the war ${ }^{35}$; while his description may be somewhat exaggerated, the Roman taxpayers were undoubtedly put under heavy $\operatorname{strain}^{36}$.

Similarly, Zeno was clearly disappointed by such a course of events, so that he proceeded to do whatever was in his power to sabotage the Hunnic politics of Chrysaphius ${ }^{37}$. Zeno's actions put him at odds with the emperor; in consequence, the former was forced to leave Constantinople and go into hiding. Interestingly enough, the person who was sent to find him was Maximinus. It would seem, therefore, that Maximinus was a supporter of Chrysaphius and Theodosius II's policies. Similarly, he was privy to Chrysaphius's plot, organized together with certain Hunnic nobles to kill Attila ${ }^{38}$. Therefore, Priscus's superior was likely

\footnotetext{
${ }^{34}$ It has been generally assumed in the literature that Attila's claims to the conquered territories were justified by the first peace with Anatolius of 447, A.H.M. Jones, The Later..., p. 194; O. MAEnchen-Helfen, The World..., 124; R. Hohlfelder, Marcian's Gamble. A Reassessment of Eastern Imperial Policy toward Attila AD 450-453, AJAH 9, 1984, p. 55; T. Stickler, Aëtius. Gestaltungsspielräume eines Heermeisters im ausgehenden Weströmischen Reich, München 2002, p. 123. As a matter of fact, however, it is more likely that Attila simply occupied those lands to pressure the Eastern Roman government into giving in to his other demands, B. Croke, Anatolius..., p. 169; J. Prostko-ProSTYŃski, Attila..., p. 139.

${ }^{35}$ Priscus, fr. 9, 3.

${ }^{36}$ C.D. Gordon, The Age of Attila. Fifth-Century Byzantium and the Barbarians, Michigan 1961, p. 66-67; O. Maenchen-Helfen, The World..., p. 114; N. Lensky, Captivity among the Barbarians and Its Impact on the Fate of the Roman Empire, [in:] The Cambridge..., p. 235-238. It should be noted that some researchers downplay the severity of the taxes: E.A. Thompson, The Foreign Policies of Theodosius II and Marcian, Her 76, 1950, p. 73; A.H.M. Jones, The Later..., p. 206-207. We should not forget, however, that the additional taxes were imposed on citizens who had just experienced the Hunnic hordes, an earthquake, and a plague. In view of this, Priscus's viewpoint seems more justified. An interesting point is also put forth by A.D. LeE (The Eastern..., p. 45, an. 77): he argues that the tributes to the Huns must have been a heavy burden on the Empire indeed, since when Marcian decided to stop paying himself off, he was able to collect impressive amounts of wealth in his treasury in just 7 years of his reign.

${ }^{37}$ One of Attila's demands was that the Emperor provide a high-born woman as a bride for a certain Constantiolus (who had earlier agreed to give the dowry to the king). Theodosius consented to that and picked a suitable candidate; however, when Zeno heard of this, he kidnapped the woman and married her off to one of his subordinates. Predictably, this resulted in a scandal - PRIscus, fr. 14; K. Feld, Barbarische..., p. 218-219; R. Kosiński, The Emperor Zeno. Religion and Politics, trans. M. FIJAK, Cracow 2010 [= BSC, 6], p. 61.

${ }^{38}$ Priscus (fr. 11) states that Maximinus did not know about Chrysaphius's plot. Yet this is improbable; in all likelihood, the historian is simply protecting his superior. Aside from the fact that Maxi-
} 
to have been part of the political equation - perhaps even not as a pawn, but as an active figure indeed.

It is most likely that the remarks that Berichus accused Maximinus of making took place during a conversation with Attila, when the men were deciding who should lead the next foreign embassy. Attila expected the Romans to send the highest-ranking officials, and Priscus notes that he meant Anatolius, Nomus, or Senator ${ }^{39}$. All the same, it has been pointed out that Attila probably mentioned two other names as well - to wit, Aspar and Areobindus ${ }^{40}$. They were both of proconsular rank and had already led an embassy to the Huns, so it is likely that Attila would have been satisfied with any of these five. But - if Berichus is to be believed - at that moment Maximinus protested by claiming that Attila's request was pointless in regard to Aspar and Areobindus, because, according to the envoy, they held no political power at the court and were supposedly unreliable. As was mentioned before, his act at Attila's court was politically motivated; most likely, the people he had named were the only ones he considered trustworthy. Nomus was a staunch supporter of Chrysaphius and - by extension - his Hunnic policy of reconciliation. Flavius Senator probably belonged to the same camp. Anatolius, despite being a military commander, also supported this policy, which explains why he was eventually chosen as the envoy accompanying Nomus in the embassy of 449 .

What Chrysaphius needed in order to ensure the success of his attempts was both the goodwill of Attila and a consistent Roman policy in that regard. That, however, proved difficult in view of the political scandal orchestrated by Zeno. If Aspar and Areobindus were in the same political camp, they could sabotage Chrysaphius's policies even further. There had been an example in the RomanHunnic relations when two different officials wanted to conduct talks with the Huns; one of them, Plintha, convinced a Hunnic noble to ask king Ruga to conduct the talks exclusively with him and ignore the other envoy ${ }^{41}$. This situation shows that there was a reasonable fear that Aspar or Areobindus might sabotage the embassies of Anatolius and Nomus.

This, however, means that Maximinus's claims were actually false, meant to mislead Attila into dealing solely with Chrysaphius's faction. Accordingly, Berichus's outburst upon his learning what Maximinus said to Attila appears understandable: he knew enough about Roman politics to realize that Maximinus was lying. $\mathrm{He}$

minus should have known about the conspiracy in view of being the leader of the embassy, there is a passage in PRIScus (fr. 11) in which he clearly tried to evaluate whether Onegisius could be introduced to it (the Hun decided to remain loyal to his king, however).

${ }^{39}$ Priscus, fr. 13.

${ }^{40}$ B. Croкe (Anatolius..., p. 166) claims that Attila mentioned Aspar and Areobindus alongside Anatolius, Nomus and Senator because they had already conducted talks with the king. As a result, they would have been 'proven' in his eyes.

${ }^{41}$ PRISCUS, fr. 2. 
had probably fought in the war himself, and knew that Aspar and Areobindus were no less formidable than the other commanders. Nonetheless, it is doubtful that he knew the real reasons behind the envoy's actions; rather, he probably understood Maximinus's words as yet another attempt on the part of the Romans to swagger and twist the truth, and to depict the Hunnic achievements as less worthy. This hurt his personal pride ${ }^{42}$.

Considering the above analysis, we can present a new reconstruction of the events of 447-449. At the beginning of the Hun invasion of 447, the Roman armies failed to join forces. One of their detachments, led by Arnegisclus and travelling to meet the remainder of the army, got caught by the Hunnic forces on the river Utus and was defeated, with the Huns taking a heavy toll. The remaining generals Aspar and Areobindus decided not to risk an engagement and retreated from the Hunnic hordes. When Attila approached Constantinople, they joined Anatolius's forces as well as Zeno's Isaurians and managed to prevail in the battle of Chersonesus, though by no means decisively. At that point, however, Theodosius II and Chrysaphius decided not to risk further war and to find settlement quickly. They dispatched Anatolius, the only commander who agreed with their plans. Yet this was at odds with Zeno's ambition to continue the war, and it is likely that the other commanders, Aspar and Areobindus, were of a similar opinion ${ }^{43}$. This posed a problem for the government, because Zeno went as far as to sabotage the above-mentioned diplomatic attempts. Chrysaphius could not risk having someone meddle in his affairs, and therefore needed trusted people to conduct diplomacy with Attila. This was the reason why Maximinus accepted three names out of the five suggested by Attila: the envoy knew that Aspar and Areobindus would not agree with the political goals set by Chrysaphius.

To conclude, the analysis of Berichus's story and the surrounding events provides evidence for faction struggle after the war of 447 , focused on how to resolve the conflict with the Huns. The argument between Chrysaphius and his opponents was not motivated merely by drive for power and religious politics; they also wanted the country to pursue a different policy towards the Huns. This was most evidently true in the case of Zeno the Isaurian. However, the fact that Chrysaphius clearly did not entrust either Aspar or Areobindus with conducting the diplomatic talks with the Huns proves that they were also conflicted with the eunuch, possibly along the lines of how to tackle the Hun problem. If Aspar was truly

\footnotetext{
${ }^{42}$ We have an example of a very similar diplomatic scandal at the beginning of the journey of Priscus's embassy, when the interpreter Vigilas said that one could not compare Attila to the emperor Theodosius, since the former was a man while the latter was god. This obviously angered the Huns, who only calmed down after they had been given valuable gifts - PRIscus, fr. 11, 2.

${ }^{43}$ Although we do not have direct evidence for that, we know that Aspar was a political opponent of Chrysaphius and that the later emperor Marcian, who was certainly somewhat dependent on Aspar, embarked on a hard-line policy towards the Huns.
} 
a proponent of military action against Attila, it would explain how he could find common ground with Flavius Zeno, as well as provide another argument in support of the current scholarly consensus on the alliance between these two figures against Chrysaphius. Nevertheless, it is important to note that Aspar and Zeno might have been cooperating longer than generally thought. Finally, Maximinus's claims about Aspar were only meant to mislead Attila and cannot be taken as an argument for the evaluation of Aspar and Areobindus's position at the court. It is very likely that their influence did not suffer as severely during the war with the Huns, and that they remained powerful figures in Byzantine politics. Altogether, the short and seemingly unimportant fragment in Priscus's histories provides extensive evidence for re-evaluating our perspective on the events of 447-450 as well as Aspar's power, political goals and alliances during that time.

\section{Bibliography}

\section{Primary Sources}

Chronica Gallica a. CCCCLII, [in:] Chronica Gallica, ed. T. Mommsen, Berolini 1892, p. 646-662 [= Monumenta Germaniae historica, Auctores antiquissimi].

The Chronicle of Marcellinus, ed. et trans. B. Croke, Sydney 1995 [= Byzantina Australiensia, 7].

Chronicon Paschale, vol. I-II, ed. L. Dindorfius, Bonnae 1832 [= Corpus scriptorum historiae byzantinae, 14-15].

The Ecclesiastical History of Evagrius Scholasticus, ed. et. trans. M. Wнітвy, Liverpool 2000 [= Translated Texts for Historians, 33].

Ioannis Malalae Chronographia, rec. I. ThuRn, Beriolini-Novi Eboraci 2000 [= Corpus fontium historiae byzantinae. Series Berolinensis, 35].

Iordanes, Romana, [in:] Iordanis Romana et Getica, rec. T. Mommsen, Berolini 1882, p. 1-52 [= Monumenta Germaniae historica, Auctores antiquissimi $]$.

Priscus, Fragmenta, [in:] The Fragmentary Classicising Historians of the Later Roman Empire. Eunapius, Olympiodorus, Priscus and Malchus, ed. et trans. R.C. BLOCKLEY, vol. II, Liverpool 1983, p. 221-401.

Procopius, History of the Wars, vol. II, Books 3-4. (Vandalic War), trans. H.B. Dewing, Cambridge Massachusetts 1916 [= Loeb Classical Library, 81].

Theophanis Chronographia, vol. I-II, rec. C. DE BooR, Lipsiae 1883-1885.

\section{Secondary Literature}

Altheim F., Geschichte der Hunnen, vol. IV, ${ }^{2}$ Berlin 1975.

Bachrach B., A History of the Alans in the West. From Their First Appearance in the Sources of Classical Antiquity through the Early Middle Ages, Minneapolis 1973. 
Bleeker R.A., Aspar and Attila: The Role of Flavius Ardaburius Aspar in the Hun Wars of the 440s, "Ancient World" 3, 1980, p. 23-28.

Blockley R.C., East Roman Foreign Policy. Formation and Conduct from Diocletian to Anastasius, Leeds 1992.

Bóna I., Das Hunnenreich, Stuttgart 1991.

Burgess R.W., The Accession of Marcian in the Light of Chalcedonian Apologetic and Monophysite Polemic, "Byzantinische Zeitschrift" 86/87, 1994, p. 27-68.

Burns T.S., A History of the Ostrogoths, Bloomington 1984.

Bury J.B., History of the Later Roman Empire from the Death of Theodosius I to the Death of Justinian, AD 395 to AD 565, London 1923.

Croke B., Anatolius and Nomus: Envoys to Attila, "Byzantinoslavica” 42, 1981, p. 159-170.

Croke B., Dynasty and Ethnicity. Emperor Leo I and the Eclipse of Aspar, "Chiron" 35, 2005, p. 147-203.

Demandt A., Geschichte der Spätantike, ${ }^{2}$ München 2008 [= Alte Geschichte in Beck's historischer Bibliothek].

FELD K., Barbarische Bürger. Die Isaurier und das Römische Reich, Berlin 2005.

Gautier E., Genséric. Roi de Carthage, Paris 1951.

GLušAnin E.P., Voennaja znat' rannej Vizantii, Varnaul 1991.

Gordon C.D., The Age of Attila. Fifth-Century Byzantium and the Barbarians, Michigan 1961.

Heather P., Goths and Romans 332-489, Oxford 1991 [= Oxford Historical Monographs].

Hohlfelder R.L., Marcian's Gamble. A Reassessment of Eastern Imperial Policy toward Attila $A D$ 450-453, "American Journal of Ancient History" 9, 1984, p. 54-69.

Holum K.G., Theodosian Empresses. Women and Imperial Dominion in Late Antiquity, BerkeleyLondon 1981.

Jones A.H.M., The Later Roman Empire 284-602. A Social, Economic and Administrative Survey, Oxford 1964.

Karayannopulos J., Byzantinische Miszellen, [in:] Studia in honorem Veselini Beševliev, ed. V. GeorGIEv, Sofia 1978.

Kelly C., Neither Conquest nor Settlement: Attila's Empire and Its Impact, [in:] The Cambridge Companion to the Age of Attila, ed. M. MAAs, Cambridge 2015 [= Cambridge Companions to the Ancient World], p. 193-208.

Kiм H.J., The Huns, Romans and the Birth of Europe, Cambridge 2013.

Kosıński R., The Emperor Zeno. Religion and Politics, trans. M. FIJAK, Cracow 2010 [= Byzantina et Slavica Cracoviensia, 6].

Laniado A., Aspar and His Phoideratoi: John Malalas on a Special Relationship, [in:] Governare e riformare l'impero al momento della sua divisione. Oriente, Occidente, Illirico, ed. U. Roberto, L. Mecella, Rome 2016, p. 325-344 [= Collection de l'École française de Rome, 507].

Lee A.D., The Eastern Empire: Theodosius to Anastasius, [in:] Cambridge Ancient History, vol. XIV, ed. A. Cameron, B. Ward-Perkins, M. Whitby, Cambridge 2008, p. 33-62.

LeE A.D., Theodosius and His Generals [in:] Theodosius II. Rethinking the Roman Empire in Late Antiquity, ed. C. Kelly, Cambridge-New York 2013 [= Cambridge Classical Studies], p. 90-108. 
Lensky N., Captivity among the Barbarians and Its Impact on the Fate of the Roman Empire, [in:] The Cambridge Companion to the Age of Attila, ed. M. MAAs, Cambridge 2015, p. 230-246.

Maenchen-Helfen O., The World of Huns. Studies in Their History and Culture, ed. M. Knight, Berkeley-London 1973.

McEvoy M., Becoming Roman? The Not-So-Curious Case of Aspar and the Ardaburii, "Journal of Late Antiquity" 9, 2016, p. 483-511.

Prostko-Prostyński J., Attila and Novae, [in:] Novae. Legionary Fortress and Late Antique Town, vol. I, A Companion to the Study of Novae, ed. T. Derda, P. DyczeK, J. Kolendo, Warsaw 2008, p. 133-140.

Rouche M., Attila. La violence nomade, Paris 2009.

Sсотт L., Aspar and the Burden of Barbarian Heritage, "Byzantine Studies / Études byzantines" 3, 1976, p. 59-69.

Stein E., Histoire du Bas-Empire, Paris 1959.

STICKLER T., Aëtius. Gestaltungsspielräume eines Heermeisters im ausgehenden Weströmischen Reich, München 2002.

Stickler T., Die Hunnen, München 2007.

Thompson E.A., The Foreign Policies of Theodosius II and Marcian, "Hermathena" 76, 1950, p. 58-75.

Thompson E.A., A History of Attila and the Huns, Oxford 1948.

Thompson E.A., The Isaurians under Theodosius II, "Hermathena" 48, 1946, p. 18-31.

Tyszkiewicz L., Hunowie w Europie. Ich wplyw na Cesarstwo Wschodnie i Zachodnie oraz na ludy barbarzyńskie, Wrocław 2004 [= Acta Universitatis Wratislaviensis, 2695].

Urbaniec A., Wpływ patrycjusza Aspara na cesarska elekcję Leona, "U Schyłku Starożytności. Studia Źródłoznawcze" 11, 2011, p. 173-201.

Vernadsky G., Flavius Ardabur Aspar, "Südost-Forschungen” 6, 1941, p. 38-72.

Vössıng K., Das Königreich der Vandalen. Geiserichs Herrschaft und das Imperium Romanum, Darmstadt 2014.

WiLCzyŃski M., Gejzeryk i “czwarta wojna punicka”, Oświęcim 2016.

Wirth G., Attila. Das Hunnenreich und Europa, Stuttgart 1999.

Zuckermann C., L'Empire d'Orient et les Huns. Notes sur Priscus, “Travaux et mémoires du Centre de recherches d'histoire et civilisation byzantines" 12, 1994, p. 159-182.

Abstract. The article examines Priscus's account of the conflict that emerged between the leader of
the Roman embassy, Maximinus, and the Hunnic envoy, Berichus. The barbarian got offended by
the remarks concerning the lack of competence and influence of Aspar and Areobindus. A detailed
analysis of this short passage - entailing the persona of Berichus himself, the reasons for his anger,
and the possible explanations for Maximinus's behaviour - can provide us with evidence regarding
the political position of Aspar in the last years of the reign of Theodosius II. Most scholars use this
example to illustrate Aspar's falling out of favour and power; it is more likely, however, that the situ-
ation was actually more complex. The political struggle between Chrysaphius, a proponent of the
policy of reconciliation with the Huns, and Zeno, the opponent of such policies, makes it far more
probable that the government feared that their diplomatic effort might be hijacked by the opposing 
faction. Therefore, it was political differences - and not the failures in the war of 447 - that were the reason for Aspar's falling out with the emperor. This would also mean that Zeno and Aspar shared similar views on how to solve the Hunnic problem, which would be the basis for their cooperation, resulting in the overthrowing of Chrysaphius and the crowning of Marcian in 450.

Keywords: Byzantium, Huns, Aspar, Theodosius II, Byzantine foreign policy, Byzantine military elite.

Eukasz Pigoński

Uniwersytet Łódzki

Wydział Filozoficzno-Historyczny,

Instytut Historii

Katedra Historii Bizancjum

ul. Kamińskiego 27a

90-219 Łódź, Polska/Poland

pigonski@zoho.com 